\title{
Korrespondensie
}

\section{DIE NUWE CHEMIEWOORDEBOEK}

Ek wil graag 'n ernstige inkonsekwensie in bogenoemde woordeboek onder u aandag bring.

Decane word as dekaan vertaal terwyl decene as deseen vertaal word.

Die algemene woorde is alkatan en alkeen. Vir nege koolstofatome is dit nonatu en noneen. Vir agt koolstofatome is dit oktaun en okteen. Daar is geen taalkundige of ander rede om by tien koolstofatome van die algemene patroon af te wyk nie. Ek sou dus voorstel dat die gebruiklike terme dekaan en dekeen behoue bly.

H.D. Nelson

Departement Chemie

Potchefstroomse Universiteit vir C.H.O.

Privaat sak X6001

Potchefstroom

2520

\section{Termomskrywings}

Omdat outeurs nie altyd weet wat met die terme navorsingsbrief, navorsingsartikel en oorsigartikel bedoel word nie, word hier 'n kort omskrywing van hierdie terme gegee:

- 'n Navorsingsbrief is 'n kort bekendstelling van navorsing waarmee die outeur besig is, of wat pas afgehandel is. Dit kan 'n uitgebreide navorsingsartikel oor die betrokke onderwerp voorafgaan.
- 'n Navorsingsartikel behandel 'n meer uigebreide en afgeronde stuk navorsingswerk en sluit 'n kritiese bespreking van die resultate in.

- 'n Oorsigartikel is 'n kritiese verslag van navorsing en kundigheid in 'n gespesialiseerde gebied. gerig op vakgenote. 
Alle illustrasies, hetsy lyntekeninge, grafieke of fotografiese reproduksies, word figure* genoem. Die benaderde posisie van figure in die teks moet aangedui word.

Een stel oorspronklike figure of glansfoto's en drie stelle kopieë moet voorgelê word. Die figuurnommer en die naam van die outeur of eerste outeur moet agterop elkeen van die figure aangedui word. Daar moet ook agterop elkeen van die figure aangedui word watter kant van die figuur bo moet wees deur 'n pyltjie te teken en daarby die woord "bo" aan te bring.

Figure wat van lyntekeninge gebruik maak, moet met lyndiktes van minstens $0,7 \mathrm{~mm}$ op A4 wit papier van goeie gehalte geteken word. Die tekening moet die hele A4-vel met 'n kantlyn van minstens $40 \mathrm{~mm}$ aan alle kante van die tekening vul. In die geval van grafieke moet die lyndiktes van die asse $0,35 \mathrm{~mm}$ wees sodat die krommes met $0,7 \mathrm{~mm}$ lyndikte duidelik uitstaan. Die asse van die grafiek moet op geskikte intervalle afgemerk wees. Die merkies moet na binne wys, $0,25 \mathrm{~mm}$ dik wees en buite geannoteer word. Roosterlyne $(0,25 \mathrm{~mm}$ dik) moet vermy word behalwe waar noukeurige afmetings op die krommes nodig is Hoofletters wat by A4-lyntekeninge gebruik word, moet ten minste $5 \mathrm{~mm}$ hoog wees en die klein letters moet bypassend wees.

Daar moet baie duidelik onderskei word tussen die verskillende krommes wat op 'n grafiek aangebring word deur of syfers, letters of simbole (sirkels, driehoekies, kruisies, ens.) op die lyne aan te bring, of van verskillende lyntipes (soliede, stippellyne, stippelpuntlyne ens.) gebruik te maak. Die betekenis van die simbole of lyntipes moet indien nodig in die onderskrif verduidelik word.

Die beskrywing van die asse van grafieke moet buite wees en moet, waar toepaslik, bestaan uit 'n woord (bv. versnelling), 'n simbool (bv. a) en 'n eenheid (bv. $\mathrm{ms}^{-2}$ ). Byskrifte moet parallel met die asse wees.

Foto's moet in so 'n grootte voorsien word dat dit regstreeks afgedruk kan word. Die wydte moet hoogstens of $160 \mathrm{~mm}$ (bladsywydte) of $80 \mathrm{~mm}$ (kolomwydte) wees. In elk geval moet die foto's so klein as moontlik wees sonder om detail te verloor.

Lynfigure sowel as foto's moet voorsien wees van 'n onderskrif wat op 'n afsonderlike vel getik word, met verwysing na die figuurnommers wat agterop die oorspronklike figuur aangedui is.

(Sien bygaande voorbeeld.) 